\title{
Mathematical Representation of Students in Solving Mathematic Problems Reviewed from Extrovert-Introvert Personality
}

\section{Aulia Ar Rakhman Awaludin ${ }^{1 *}$, Noni Selvia ${ }^{2}$, Finata Rastic Andrari ${ }^{3}$}

\author{
1,2,3 Universitas Indraprasta PGRI, Jakarta, Indonesia
}

\section{ART ICLE INF O}

Article history:

Received March 20, 2021

Revised March 21, 2021

Accepted May 11, 202

Available online May 25, 2021

Kata Kunci:

Representasi Matematis, Kepribadian

Keywords:

Mathematical Representation, Personality

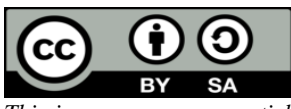

This is an open access article under the CC BY-SA license.

Copyright (C) Universitas

Pendidikan Ganesha. All rights reserved.

\begin{abstract}
A B S T R A K
Dalam pelaksanaan pembelajaran matematika di sekolah, pendidik harus memperhatikan lima standar kompetensi utama, yaitu pemecahan masalah, komunikasi, koneksi, penalaran, dan representasi. Representasi matematis adalah alat untuk menyampaikan pemikiran aljabar siswa sebagai bantuan untuk membangun ide-ide mereka tentang pola dan fungsi. Penelitian ini bertujuan untuk mengkaji tentang representasi matematis siswa ditinjau dari tipe kepribadian introvert dan ekstrovert. Untuk melihat karakteristik representasi matematis dalam menyelesaikan masalah matematika jika dilihat dari tipe kepribadian masing-masing siswa. Metode penelitian ini adalah deskriptif kualitatif. Jumlah sekolah dan siswa yang dijadikan sampel dari penelitian ini diambil dengan teknik pengumpulan data bertahap (multistage sampling). Instrumen pengumpulan data dalam penelitian ini adalah angket kepribadian, tes pemecahan masalah, wawancara, observasi, dan dokumen yang diperoleh dari subjek penelitian. Analisis pemecahan masalah yang digunakan berdasarkan langkah Krulik dan Rudnik. Tipe kepribadian siswa ekstrovert dan siswa introvert memang memiliki pola pikir yang berbeda sehingga walaupun dalam beberapa langkah menggunakan representasi yang sama tetapi kecenderungan atau kebiasaannya merepresentasikan suatu pemecahan masalah menggunakan bentuk representasi yang berbeda. Tipe kepribadian siswa ekstrovert lebih mewakili mereka secara simbolis dan hampir semua jawaban dari siswa tipe ekstrovert mendekati benar jika dibandingkan dengan siswa introvert.
\end{abstract}

\section{A B S T R A C T}

In implementing mathematics learning in schools, educators must pay attention to five main competencies, namely problem solving, communication, connection, reasoning, and representation. Mathematical representation is a tool to convey students' algebraic thinking as an aid to construct their ideas about patterns and functions. This study aims to examine the mathematical representation of students in terms of introvert and extrovert personality types. To see the characteristics of mathematical representations in solving mathematical problems when viewed from the personality type of each student. This research method is descriptive qualitative. The number of schools and students who were sampled from this study was taken using a multistage sampling technique. The data collection instruments in this study were personality questionnaires, problem-solving tests, interviews, observations, and documents obtained from research subjects. The problem-solving analysis used is based on the Krulik and Rudnik steps. The personality types of extroverted students and introverted students do have different mindsets so that even though in some steps they use the same representation, their tendencies or habits represent problem-solving using different forms of representation. The personality types of extroverted students represent them more symbolically and almost all answers from extroverted students are closer to true when compared to introverted students.

\section{INTRODUCTION}

National Council of Teacher of Mathematics (NCTM) states that in implementation of mathematics learning in school, educators must pay attention to the five main competency standards, that is problem solving, communication, connection, reasoning, and representation (Lee et al., 2018; Smith et al., 2018). In the process of learning mathematics, the ability to express and represent mathematical ideas is something that must be done by every person who learn mathematics (Cho \& Tee, 2018; Ishak et al., 2020). In addition, function of mathematics is for developing of communication skills using numbers and symbols as well as sharpness of reasoning that can help solve problems in real life (Gurat, 2018; Ke \& Clark, 2020).

Mathematical representation is a tool to convey students algebraic thinking as an aid to constructing their ideas about patterns and functions (Ratnasari et al., 2018; D. P. Sari, 2018). Mathematical representation is a process of modeling something from the real life into abstract concepts and symbols (Hwang et al., 2007). The representations used in mathematics education into five types. They are representations of real world objects, concrete representations, arithmetic symbol 
representations, verbal language representations, and image or graphic representations (Rahmawati et al., 2017; Ratnasari et al., 2018). Furthermore, the ability of representation can support students in understanding mathematical concepts that are learned and communicating mathematical ideas, understanding connections between mathematical concepts, and applying mathematics to realistic mathematical problems through mathematical modeling (Gagatsis \& Elia, 2004; Wieczorek \& Lewandowski, 2017). This is also seen in the other results of research reveal that students' understanding and representation abilities are the key to getting the right problem solving solutions (Gagatsis \& Elia, 2004; Zazkis \& Liljedahl, 2004). However, in reality the ability of students in Indonesia to represent mathematical problems is low. The results of the TIMSS 2011 survey show that Indonesia's mathematical ability is low competitiveness with other countries, where Indonesia is ranked 38th out of 42 surveyed countries (Mullis et al., 2016; Pribadi et al., 2015).

Problem solving ability is the goal of learning mathematics, therefore problem solving abilities must be possessed by every students (Ningsih et al., 2020; Root et al., 2020). There are several types of problem solving in solving it, one of which is Krulik and Rudnick's steps. The problem solving steps by Krulik dan Rudnick are (1) read and think, (2) explore and plan, (3) select a strategy, (4) find an answer, and (5) reflect and extend. Each student has a different way of conveying, constructing, and solving a problem (Krulik \& Rudnick, 1995). This difference shows the factors of different personality types among students, thus influencing students to convey, construct, and solve a problem. One way to solve this problem is to group them according to their creativity level to respect each student and not see them as similar (Awaludin et al., 2017). Contextual-based learning provides opportunities for students to construct mathematical concepts that are being studied so that students are actively involved in the learning process (Setiawan \& Harta, 2014). Student involvement will strengthen their understanding of mathematical concepts.

One of the internal factors that affect students' problem solving abilities is motivation and potential (Schmitt \& Bradburn, 2018). Potential is a factor that students have that is closely related to their personality (Milliano, 2020; Yang \& Li, 2018). The potential in students can be in the form of different personalities that can affect the thinking process. the character in the personality field, Jung, believed that when he knew the nature and direction of psychic energy in a person, he could indirectly know what he thought (Khorshidi, 2013). Therefore, by understanding and describing the inner feelings of an individual and presenting a descriptive frame of mind, the characteristics of a person can be determined more easily so that a deeper understanding can be obtained to increase self-awareness. Thus, the thought process will be related to the direction of psychic energy or personality that students have. Jung suggested two personalities, namely extrovert and introvert personality (Samand et al., 2019; Yuliani et al., 2019). Based on research regarding the significant differences between extrovert and introvert individuals to simple reactions to conflict situations, it is concluded that introverted individuals who are focused and afraid of failure make them more careful, make fewer mistakes, but take more time to think (Burtăverde \& Mihaila, 2011). In contrast, extrovert personalities respond more quickly but are prone to errors because they focus more on the environment rather than on themselves, extrovert individual have lower concentration abilities than introverted individual.

Extrovert personality is influenced by the objective world in the form of something outside himself (D. K. Sari et al., 2019; Suryabrata, 2007). Aspects of thoughts, feelings, and actions are determined by the environment, both social and non-social environment. Unlike the extrovert personality, the introvert personality is influenced by the subjective world of something within itself. Aspects of thoughts, feelings, and actions are determined by subjective factors. It can be concluded that extroverts-introverts have different sources of energy for their own individuals, so that there will be different thought processes that will be obtained from different aspects of the mind. Based on this, it can be said that different personalities are likely to produce different thought processes. . This study discusses the mathematical representation of students in terms of introvert and extrovert personality types. In order to see the characteristics of mathematical representation in solving mathematical problems if seen from the personality type of each student.

\section{METHOD}

This research is a descriptive qualitative research. The number of schools and students who were sampled from this study was taken by using a multistage sampling technique. Meanwhile, to determine the research subject using the criterion-based selection model which is based on the assumption that the subject is an actor in the proposed research theme. In addition, in determining information, the snow ball sampling model can be used to expand the research subject. Respondents of this study were students in East Jakarta. Collecting data in this study were personality questionnaires, problem solving tests, 
interviews, observations, and documents obtained from research subjects. Problem solving analysis used based on Krulik and Rudnick steps. They are are (1) read and think, (2) explore and plan, (3) select a strategy, (4) find an answer, and (5) reflect and extend (Krulik \& Rudnick, 1995).

Data processing is carried out in several stages. The first stage of data processing starts from preliminary research to the compilation of research proposals. The second stage of data processing is carried out by processing the results of interviews and collecting various field information at the research location. The third stage is checking the validity of the data from interviews with a number of sources who are used as research informants and comparing the data with various related information. At this stage, data processing is considered optimal if the data obtained is considered complete and can represent the problem that is the object of research. The final stage is data analysis in order to answer the research questions carried out by using the triangulation analysis approach.

\section{RESULT AND DISCUSSION}

\section{Result}

After obtaining the results of the reduction in the field notes from the first, second and third data collection, the next step is to triangulate the time by comparing the results of the first, second, and third collection. Then obtained the same or valid data. If different data is obtained, the data is reduced. Based on the results of the analysis, there are similarities between the first data collection and the second data collection. From this similarity, it is obtained about the use of representations for students in solving problems in the linear equation material of two variables at each stage of Krulik and Rudnick. Table 1 shows the results of the analysis related to the forms of mathematical representations used by extrovert personality students and introverted personality students.

Table 1. Results of Using Mathematical Representation Forms Students with extrovert-introvert personality.

\begin{tabular}{|c|c|c|c|}
\hline $\begin{array}{l}\text { Personality } \\
\text { Types }\end{array}$ & $\begin{array}{c}\text { Krulik and } \\
\text { Rudnick steps }\end{array}$ & Problem Solving Description & $\begin{array}{l}\text { Representation } \\
\text { Form }\end{array}$ \\
\hline & $\begin{array}{l}\text { Read and Think } \\
\text { Explore and Plan }\end{array}$ & $\begin{array}{l}\text { In this two stage position, students } \\
\text { both use words to convey what is } \\
\text { known and asked after writing first. } \\
\text { How to convey too fast so it is not } \\
\text { clear, only write down what is } \\
\text { known. }\end{array}$ & Verbal \\
\hline Extrovert & Select and Strategy & $\begin{array}{l}\text { In this stage, students use symbols to } \\
\text { take the known information using } x \\
\text { and y then write down the } \\
\text { information in the form of linear } \\
\text { equations correctly, the comparison } \\
\text { formula, write the formula to } \\
\text { determine the interest each month, } \\
\text { then this formula is used to find the } \\
\text { answer or the final result. how to } \\
\text { operate a linear equation. }\end{array}$ & Symbolic \\
\hline
\end{tabular}

Reflect and Extend Students use symbols when asked

Symbolic about possible new problems. Students are less precise in conveying or changing the problem into the form of a mathematical model.

Read and Think In these two stages, students convey Introvert $\quad$ Explore and Plan what they know and are asked to use words slowly and clearly and correctly, write them completely and

Verbal and Visual 


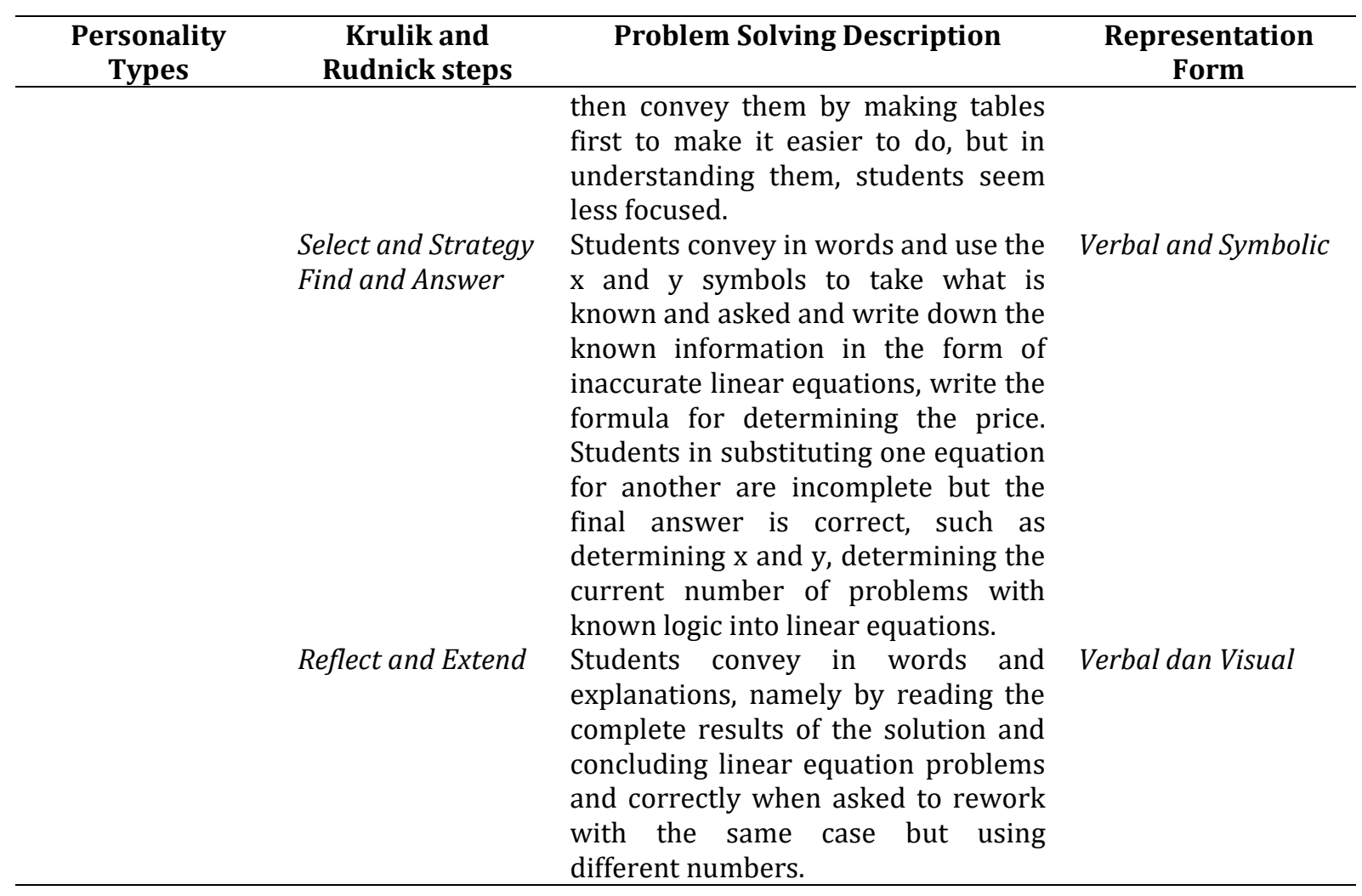

\section{Discussion}

The use of various forms of representation (including verbal, visual, and symbolic representations) is an inseparable part of learning. This is in line with previous study that in constructing mathematical concepts, students must be able to construct in a way that can be understood by relating their ideas to meaningful articulations of various representations (Son, 2020; Supandi et al., 2018; Surya \& Putri, 2017). In constructivism theory, students' knowledge is the result of a construction from the students themselves. Knowledge is a cognitive construct that occurs through a series of one's activities. The series of activities referred to involves the use of multiple representations. Based on the results of this study, the subject of extroverted personality (SE) shows the use of multiple representation in solving mathematical problems in Krulik and Rudnick's steps, namely in the Reflect and Extend step. The subject uses a form of visual and symbolic representation. Subjects are asked to solve problems that have been previously given in the mathematical model and be able to represent them. However, the results obtained by the SE subject's graphic modeling are not accurate. Meanwhile, the subject of Introverted Personality (SI) shows that there is multiple representation in solving math problems in almost every step of Krulik and Rudnick. However, it appears that the use of visual representations is still lacking. This is because teachers rarely use visual representations when learning at school, so it requires additional time. This is in accordance with the research which revealed that The opinions of the students about the use of visual representations and the positive relationship between the use of visual representation and problem solving shows the need for teachers to give much more time to using visual representations in problem solving (Guler \& Çiltas, 2011; Siagan et al., 2019; Simamora \& Saragih, 2019).

The following describes the uses of extroverted personality (SE) students' mathematical representations in solving mathematical problems on linear equations. The use of mathematical representations of students in solving problems using Krulik and Rudnick's steps on linear equation material is known by giving students mathematical problems then asking them to solve these problems using Krulik and Rudnik's steps. There are three types of using the mathematical representation form of students in solving math problems. The three types include verbal representation, symbolic representation, and visual representation. The researcher used three indicators to determine the use of verbal representations, namely 1) writing down the steps to solve the problem using words; 2) conclude or answer questions using words. Indicators for symbolic representations include, 1) making mathematical equations or models from the given representation; 2) make a conjecture from a number; 3 ) solve the problem by involving mathematical expressionsFurthermore, indicators in visual representations include, 1) using diagrams, tables or graphs to solve or conclude problems; 2) make pictures to clarify the problem and facilitate its resolution. 
Then the subject is given questions that have never been done before or non-routine problems, to determine the use of mathematical representations of students in solving social arithmetic and comparison problems in representing problem solving based on Krulik and Rudnick's steps. In the Read and think step, almost all subjects (SE-1, SE-2, SE-3, SI-1, SI-2, SI-3) use verbal representations in describing what is known and asked. Likewise, in the Explore and Plan steps, the subject (SE-1, SE-2, SE-3) uses a verbal representation, for subjects SI-1 and SI-2 a visual representation is added. There is the use of symbolic representations by all SI subjects in the Select a Strategys step, while for SE subjects add verbal representations. There is the use of symbolic representations by all SE and SI subjects in the Find an Answer step, but the SI subjects are more consistent in using symbols while SE subjects are not consistent in their use of symbolic representations. Finally, there is the use of visual and symbolic representations by SI subjects, while SE subjects use verbal and visual representations in the Reflect and Extend step.

Based on the answers of three SE subjects and 3 SI subjects, it was found that SI subjects tended to represent mathematical problems using symbolic representations based on Krulik and Rudnick's steps, while SE subjects tended to represent mathematical problems using verbal representations based on Krulik and Rudnick's steps. SE and SI personality types do have different mindsets so that even though in several steps they use the same representation, the tendency to represent solving a problem uses different forms of representation. The SI personality type represents it symbolically and almost all the answers from the SI type are closer to being correct when compared to the SE type. This is in line with research which states that the extrovert personality is influenced by the objective world in the form of the world outside himself (Sanjaya et al., 2020; Suryabrata, 2007). Aspects of thoughts, feelings, and actions are determined by the environment, both social and non-social. The extrovert person is positive towards society as shown by his nature, namely his open heart, easy to socialize, and relationships with other people run smoothly. However, the weakness of the exstrovert personality is that if the attachment to the outside world is too strong, then he will sink into the objective world and lose himself.

Previous research suggests that only a few students choose to use symbolic representations in communicating or conveying their mathematical ideas (Gagatsis \& Elia, 2004; Guler \& Çiltas, 2011; Supriadi et al., 2019). Students who focus on using algebraic (symbolic) representations describe students who have high abilities. This statement is in line with the fact that in this study the SI subject tends to represent a form of symbolic representation that has high abilities.

\section{CONCLUSION}

In the Read and Think and Explore and Plan steps, SE and SI students use verbal representations. SI students write down what they know and ask in advance in detail, and explain what is written. Meanwhile, SE students understand the problems that exist in the questions by describing them verbally, but are unable to write them in mathematical form. In the Select a Strategy and Find an Answer steps, SI students use symbolic representations by taking the known information using the $\mathrm{x}$ and $\mathrm{y}$ symbols and then writing the information into linear equations correctly as a mathematical model. Then the formula is used to find the answer or the final result by operating the algebraic equation, namely substituting one equation into another equation. Meanwhile, SE students can write the known information in the form of algebraic equations using symbols after being given several stages, then substitute one equation with another which is incomplete but the final answer is correct. In the Reflect and Extend step, SI students use a form of visual and symbolic representation when students are asked if the problem given is asked to change numbers. Then solve the problem in the same way as before. Meanwhile, SE students use verbal and visual representations by describing the method and logic of solving and concluding the problem correctly. Based on the use of students' mathematical representations in solving linear equation problems, it turns out that different representations are produced but tend to lead to certain forms of representation. This can be used as reference material for developing or conducting research related to the use of mathematical representations that have different characteristics.

\section{ACKNOWLEDGEMENT}

Appreciation and thanks to Ministry of Research, Technology, and Higher Education in National Research Competition, especially Beginner Lecturer Research (PDP) 2018. Thanks to LLDIKTI Region III Jakarta and Institute of Research and Community Service Indraprasta PGRI University with Contract Number: 032/K3/PNT/2018, 06 March 2018 and Contract Agreement Number: UNINDRA Number 0300/SKP.LT/LPPM/UNINDRA/III/2018,12 March 2018. 


\section{REFERENCES}

Awaludin, A. A. R., Kurniawan, I., \& Hartuti, P. M. (2017). Junior high school student's reflective thinking process in problem solving viewed from learning creativity. Jurnal Pendidikan Indonesia, 6(2), 154-162. https://ejournal.undiksha.ac.id/index.php/JPI/article/viewFile/9963/8574.

Burtăverde, V., \& Mihaila, T. (2011). Significant Differences Between Introvert and Extrovert People's Simple Reaction Time in Conflict Situation. Romanian Journal of Experimental Applied Psychology, $2(3), 18-24$.

Cho, Y.-A., \& Tee, F.-D. (2018). Complementing Mathematics Teachers' Horizon Content Knowledge with an Elementary-on-Advanced Aspect. Pedagogical Research, 3(1), 1-11. https://doi.org/10.20897/pr/85172.

Gagatsis, A., \& Elia, I. (2004). The Effect of Different Modes of Representation on Mathematical Problem Solving. Proceedings of the 28th Conferencee of the International Group for the Psychology of Mathematics Education, 447-454. https://eric.ed.gov/?id=ED489751.

Guler, G., \& Çiltas, A. (2011). The visual representation usage levels of mathematics teachers and students in solving verbal problems. International Journal of Humanities and Social Science, 11(1), 145-154.

Gurat, M. G. (2018). Mathematical Problem-Solving Strategies among Student Teachers. Journal on Efficiency and Responsibility in Education and Science, 11(3), 53-64. https://eric.ed.gov/?id=EJ1208772.

Hwang, W.-Y., Chen, N.-S., Dung, J.-J., \& Yang, Y.-L. (2007). Multiple Representation Skills and Creativity Effects on Mathematical Problem Solving using a Multimedia Whiteboard System. Educational Technology \& Society, 10(2), 191-212. https://www.jstor.org/stable/jeductechsoci.10.2.191.

Ishak, N. H. F. B., Yusoff, N. F. B. M., \& Madihie, A. (2020). Resilience in mathematics, academic resilience, or mathematical resilience?: An overview. Universal Journal of Educational Research, 8(5 A), 34-39. https://doi.org/10.13189/ujer.2020.081905.

Ke, F., \& Clark, K. M. (2020). Game-based multimodal representations and mathematical problem solving. International Journal of Science and Mathematics Education, 18(1), 103-122. https://doi.org/10.1007/s10763-018-9938-3.

Khorshidi, H. R. (2013). Personality dimensions in distance language learning. International Journal of English and Education, 2(3), 31-38. http://ijee.org/yahoo_site_admin/assets/docs/4.17205329.pdf.

Krulik, S., \& Rudnick, J. A. (1995). The New Sourcebook for Teaching Reasoning and Problem Solving in Elementary School. Allyn \& Bacon.

Lee, Y., Capraro, R. M., \& Capraro, M. M. (2018). Mathematics Teachers' Subject Matter Knowledge and Pedagogical Content Knowledge in Problem Posing. International Electronic Journal of Mathematics Education, 13(2), 75-90. https://doi.org/10.12973/iejme/2698.

Milliano, J. (2020). Unlocking student potential: A comparison and ranking task. The Physics Teacher, 58(2), 136-137. https://doi.org/10.1119/1.5144802.

Mullis, I. V. S., Martin, M., \& Tom, L. (2016). 20 Years of TIMSS: International Trends in Mathematics and Science Achievement Curriculum and Instruction. International Association for the Evaluation of Educational Achievement (IEA).

Ningsih, F., Murni, A., \& Roza, Y. (2020). Development of Learning Tools with the Application of Learning Inventions to Improve Mathematical Problem Solving Ability Social Arithmetic Material. Journal of Educational Sciences, 4(1), 44-52. https://doi.org/10.31258/jes.4.1.p.44-52.

Pribadi, A., Somakim, S., \& Yusup, M. (2015). Pengembangan Soal Penalaran Model TIMSS pada Materi Geometri dan Pengukuran SMP. Histogram, 1(2), 115-128. https://doi.org/10.31100/histogram.v1i2.30.

Rahmawati, D., Hidayanto, E., \& Anwar, R. B. (2017). Process of mathematical representation translation from verbal into graphic. International Electronic Journal of Mathematics Education, 12(3), 367381. https://www.iejme.com/article/process-of-mathematical-representation-translation-fromverbal-into-graphic.

Ratnasari, N., Tadjudin, N., Syazali, M., Mujib, M., \& Andriani, S. (2018). Project based learning (PjBL) model on the mathematical representation ability. Tadris: Jurnal Keguruan Dan Ilmu Tarbiyah, 3(1), 47-53. https://doi.org/10.24042/tadris.v3i1.2535.

Root, J. R., Cox, S. K., Davis, K., \& Hammons, N. (2020). Contextualizing mathematical problem-solving instruction for secondary students with extensive support needs: A systematic replication. Research and Practice for Persons with Severe Disabilities, 45(4), 241-255. https://doi.org/10.1177\%2F1540796920949448.

Samand, S. M., Sailan, Z., \& Lio, A. (2019). Analysis on the relationship of extrovert-introvert personality and students' speaking performance in English study program of Halu Oleo University. Journal of 
Language Education and Educational Technology (JLEET), 4(1). https://doi.org/10.33772/jleet.v4i1.6677.

Sanjaya, A., Setiyadi, A. B., \& Munifatullah, F. (2020). The comparative study on students' speaking ability of analytical exposition text between students with extrovert and introvert personality through role-play technique. $\quad U-J E T, \quad$ 269-281. http://jurnal.fkip.unila.ac.id/index.php/123/article/view/21157.

Sari, D. K., Mulyono, M., \& Asih, T. S. N. (2019). Mathematical Problem Solving Ability Viewed from Extrovert Introvert Personality Types on Cooperative Learning Models Type Rally Coach. Unnes Journal of Mathematics Education Research, 8(2), 141-146. https://journal.unnes.ac.id/sju/index.php/ujmer/article/view/28019.

Sari, D. P. (2018). Errors of Students Learning with React Strategy in Solving the Problems of Mathematical Representation Ability. Journal on Mathematics Education, 9(1), 121-128. https: //eric.ed.gov/?id=EJ1173659.

Schmitt, N., \& Bradburn, J. C. (2018). An Ideal Student Factor and the validity of noncognitive measures of student potential. International Journal of Selection and Assessment, 26(2-4), 109-123. https://doi.org/10.1111/ijsa.12221.

Setiawan, R. H., \& Harta, I. (2014). Pengaruh Pendekatan Open-Ended Dan Pendekatan Kontekstual Terhadap Kemampuan Pemecahan Masalah Dan Sikap Siswa Terhadap Matematika. Jurnal Riset Pendidikan Matematika, 1(2), 241. https://doi.org/10.21831/jrpm.v1i2.2679.

Siagan, M. V., Saragih, S., \& Sinaga, B. (2019). Development of Learning Materials Oriented on ProblemBased Learning Model to Improve Students' Mathematical Problem Solving Ability and Metacognition Ability. International Electronic Journal of Mathematics Education, 14(2), 331-340. https://eric.ed.gov/?id=EJ1227196.

Simamora, R. E., \& Saragih, S. (2019). Improving Students' Mathematical Problem Solving Ability and SelfEfficacy through Guided Discovery Learning in Local Culture Context. International Electronic Journal of Mathematics Education, 14(1), 61-72. https://eric.ed.gov/?id=EJ1227360.

Smith, M., Bill, V., \& Raith, M. L. (2018). Promoting a Conceptual Understanding of Mathematics. Mathematics Teaching in the Middle School, 24(1), 36-43. https: //www.nctm.org/Publications/Mathematics-Teaching-in-Middle-

School/2018/Vol24/Issue1/Promoting-a-Conceptual-Understanding-of-Mathematics/.

Son, A. L. (2020). Students' Mathematical Problem-Solving Ability Based on Teaching Models Intervention and Cognitive Style. Journal on Mathematics Education, 11(2), 209-222. https: //eric.ed.gov/?id=EJ1252002.

Supandi, S., Waluya, S. B., Rochmad, R., Suyitno, H., \& Dewi, K. (2018). Think-Talk-Write Model for Improving Students' Abilities in Mathematical Representation. International Journal of Instruction, 11(3), 77-90. https://eric.ed.gov/?id=EJ1183374.

Supriadi, N., Syazali, M., Lestari, B. D., Dewi, E. S., Utami, L. F., Mardani, L. A., \& Putra, F. G. (2019). The Utilization of Project Based Learning and Guided Discovery Learning: Effective Methods to Improve Students' Mathematics Ability. Al-Ta Lim Journal, 25(3), 261-271. https://doi.org/10.15548/jt.v25i3.487.

Surya, E., \& Putri, F. A. (2017). Improving mathematical problem-solving ability and self-confidence of high school students through contextual learning model. Journal on Mathematics Education, 8(1), 85-94. https://eric.ed.gov/?id=EJ1173627.

Suryabrata, S. (2007). Psikologi Kepribadian. Rajagrafindo Persada.

Wieczorek, M., \& Lewandowski, M. (2017). A mathematical representation of an energy management strategy for hybrid energy storage system in electric vehicle and real time optimization using a genetic algorithm. Applied Energy, 192, 222-233.

Yang, F., \& Li, F. W. (2018). Study on student performance estimation, student progress analysis, and student potential prediction based on data mining. Computers \& Education, 123, 97-108. https: //doi.org/10.1016/j.compedu.2018.04.006.

Yuliani, W., Bharati, D. A. L., \& Warsono, W. (2019). The The Effectiveness of Brainstorming and Mind Mapping to Teach Writing Narrative Text for Students with Extrovert and Introvert Personalities. $\begin{array}{llll}\text { English Education } \quad \text { Journal, } & \text { 4(4), }\end{array}$ https://journal.unnes.ac.id/sju/index.php/eej/article/view/32098.

Zazkis, R., \& Liljedahl, P. (2004). Understanding Primes: The Role of Representation. Journal for Research in Mathematics Education 2004, 35(3), 164-186. https://doi.org/10.2307/30034911. 